\title{
Approaches to Pronunciation Instruction in Communicative Language Teaching Classrooms
}

\author{
Ali Babaeian \\ Faculty of Humanities, Languages, and Social Sciences, Griffith University \\ 170 Kessels Rd, Nathan QLD, Australia 4111
}

Tel: 61-756780408Ｅ-mail: alex.babaeian@gmail.com

Received: Sep. 2, $2021 \quad$ Accepted: Oct. 12, $2021 \quad$ Published: November 1, 2021

doi:10.5296/jse.v11i4.18977ＵRL: https://doi.org/10.5296/jse.v11i4.18977

\begin{abstract}
One of the main factors that affects pronunciation instruction in the classroom is the educators' teaching approach. Various elements like the L1 (first language) and cultural backgrounds influence teaching pronunciation, making English teachers deploy different pedagogical approaches for the learning process to occur. This article aims to provide insights into the pedagogical approaches used by English as a foreign language (EFL) and English as a second language (ESL) teachers in their communicative language teaching (CLT) classrooms. It will also explore the influencing variables on these approaches. To this end, five English teachers (two EFL and three ESL teachers) provided the needed data through a questionnaire and a semistructured interview for this qualitative study. The results showed that the participants used two teaching approaches for delivering pronunciation lessons, and two types of variables (i.e., student-related and teacher-related variables) influenced their choice of approach in the pronunciation classroom. Although this study is not intended to be generalized, it provides language teachers with a view of pedagogical approaches used by some EFL and ESL teachers for teaching pronunciation.
\end{abstract}

Keywords: pronunciation instruction, pedagogical approach, EFL, ESL, variables. 


\section{Introduction}

The development of L2 (second language) pronunciation is one of the most significant aspects of successful oral communication. Failure to produce, at least, understandable pronunciation of words and utterances can lead to listeners' misunderstanding and frustration (Derwing \& Munro, 2005; Levis, 2005). Attitudes toward the significance of pronunciation have been widely supported by teacher and learner views. English language learners consider pronunciation the pillar of successful verbal communication (Breitkreutz et al., 2002; Derwing, 2003; Waniek-Klimczak, 2011), and teachers regard it as an essential element in spoken language (Baker, 2011; Sifakis \& Sougari, 2005) in both EFL and ESL contexts.

Despite this consensus among learners, teachers, and scholars on the significance of L2 pronunciation in language classrooms, a pronunciation class rarely meets its objectives for various reasons (Macdonald, 2002). However, English teachers can elevate the chances of learning pronunciation by employing pedagogical approaches. These approaches are valuable implements to address various students' phonological needs.

This study explores the approaches English teachers use in EFL and ESL settings to develop learners' pronunciation and the variables affecting these approaches. Although this study cannot be generalized due to its small-scale qualitative nature, it allows language educators to rethink the approaches in their pronunciation classes.

The following research questions will establish the foundation of the study:

1) What variables influence English language teachers' approaches to teaching pronunciation lessons in EFL and ESL classrooms?

2) What approaches do English language teachers use in EFL/ESL contexts?

3) How are these approaches different?

\section{Literature Review}

\subsection{Pronunciation Learning}

Acquiring pronunciation of the target language is challenging for language learners, so they are often disinclined to learn pronunciation. Aliaga Garcia (2007), Gilakjani (2016), and Sadeghi and Mashhadi (2016) embraced this view by acknowledging that pronunciation learning is a time-consuming and arduous process for language learners; therefore, it is assumed that English educators can ease pronunciation learning by offering approaches suitable for their students.

\subsection{Communicative Language Teaching}

With the relegation of previous teaching methods in the early 1980s and the inception of CLT, language teaching shifted from a linguistic structure-centered approach to a communicative approach focusing on communicative competence. Chomsky (1957) first defined communicative competence as "capability in speech," emphasizing grammar and the audience's comprehension. In recent years it has been indicated that communicative competence consists of linguistic, discursive, sociocultural, and strategic components (Keshmirshekan, 2019). 


\section{Ml Macrothink}

Journal of Studies in Education

ISSN 2162-6952

2021, Vol. 11, No. 4

CLT has been developed based on multidisciplinary views, including linguistics, philosophy, sociology, psychology, and education, but the core of CLT is to focus on function rather than form (Richards \& Rodgers, 2014) by developing learners' functional language abilities via participation in communicative activities (Savignon, 2008). Participating in authentic, learner-centered (Desai, 2015), interactive (Richards, 2005), real-life (Brown, 2016) communicative activities such as role-play enables the learners to experience simulated social situations, consolidating linguistic features, including pronunciation (Gilakjani, 2012). Furthermore, CLT has defined a new role for teachers, shifting from "educator" to observer, participant, and facilitator in gaining communicative competence (Breen \& Candlin, 1980).

\subsection{Pronunciation Instruction in Communicative Language Classrooms}

In contrast to the previous language teaching methods and approaches, which explicitly emphasized the instruction of inner-circle (Note 1) English (Kachru, 1992) pronunciation through repetition and modeling (Nikbakht, 2010), early CLT expunged or paid scant attention to pronunciation (Celce-Murcia et al., 1996) owing to the complexity of its features, considering pronunciation a hurdle to learners' communicative practice (Binte Habib, 2013). However, CLT later presented a new view in the teaching of pronunciation by offering a replacement of intelligible for native or near-native pronunciation (James, 2010) in the classroom, as nonnative English speakers (NNESs) can hardly ever attain native pronunciation (Harmer, 2007). Field (2005) operationalized intelligible pronunciation as the degree to which the listener can recognize the acoustic-phonetic content of the spoken language, and James (2010) proposed it as the realistic goal in teaching pronunciation. The "mature version" of CLT has now suggested that pronunciation is, in fact, an integral facet of the spoken language, so it should remain an indispensable element of communicative activities (Jenkins, 2004; Marks, 2006).

The teacher engages learners in purposeful, interactive, and contextualized (Richards, 2005) communicative activities using traditional textbooks and other teaching tools such as TV, films, and the Internet. These purposeful communicative activities comprise implicit pronunciation practice, as every speaking activity is a pronunciation practice (Burns \& Seidlhofer, 2010). The teacher leads the communications among students and monitors their errors to explain them at a later time (Desai, 2015).

\subsection{Pronunciation Teaching in EFL and ESL Contexts}

Although proponents of CLT believe that CLT can be practiced in all English language teaching (ELT) settings (Richards \& Rodgers, 2014), it seems that CLT is not always effective in EFL classrooms (Hosen, 2015), and this may be the primary difference between EFL and ESL. Some problems have surfaced with implementing CLT in EFL settings. As a case in point, many EFL teachers have found it challenging to deploy CLT in their classrooms because students resist shifting from the old method (e.g., grammar-translation) to CLT (Koosha\& Yakhabi, 2013). Furthermore, EFL learners are mainly exposed to English sounds in their classrooms. With limited class time, EFL teachers have to cover all language skills in a short period (Chiu, 2008; Sung, 2005); hence, they may prioritize the "important" 
language skills over pronunciation (Hayati, 2010) and disregard pronunciation instruction (Gilakjani, 2016).

\subsection{Components of Pronunciation Pedagogy}

A useful distinction in pronunciation pedagogy is that of form and function. Pronunciation form is concerned with the mastery of pronunciation, emphasizing explicit pronunciation instruction by using techniques such as listening and repeating with scant attention to function (Saito, 2013). This approach may include the teaching of the descriptive phonological units contained within the International Phonetic Alphabet (IPA). Pronunciation function deals with describing what these phonological units do and how words and sentences are pronounced to deliver the spoken message (Dalton \& Seidlhofer, 1994). Because CLT is function-focused (Richards \& Rodgers, 2014), teachers should give priority to teaching meaning by integrating pronunciation into communicative activities for students to achieve intelligible pronunciation (Fraser, 2002; Levis \& Grant, 2003). As part of functional language, teachers should prioritize suprasegmental aspects of speech over segmentals because the former carries a more significant role in transferring functional language (Celce-Murcia et al., 1996).

Suprasegmental aspects of speech (i.e., tone, pitch, rhythm, word and sentence stress) refer to phonological properties extending to syllable, word, and phrase (Kang et al., 2010). Segmentals are the basic inventory of distinctive sounds (Florez, 1998) and consist of vowels, consonants, consonant clusters, and diphthongs (McDonough, 1999). Mispronunciation of segmentals may change the meaning of words (Burns \& Claire, 2003), causing minor repairable misunderstandings in conversation (Celce-Murcia et al., 1996). Errors at the suprasegmental level, however, seem to have more consequences and may hinder comprehensibility (Zarifi \& Sayyadi, 2015); therefore, they deserve more attention in the classroom (Fraser, 2000).

\subsection{Variables in Pronunciation Pedagogy}

Most English teachers adopt methods, approaches, and technics to address learners' phonological needs within the CLT paradigm. The following variables seem to be of great importance in securing intelligible pronunciation in the classroom:

1) Teacher cognition about pronunciation instruction;

2) Pronunciation teaching in teacher training programs;

3) Experience in teaching English;

4) Students' linguistic profiles.

\subsubsection{Teacher Cognition about Pronunciation Instruction}

The limited existing literature on teachers' cognition about pronunciation instruction (Baker, 2014) refers to their thoughts, attitudes, beliefs, and practice (Biorg, 2015) about pronunciation teaching. Research into teacher cognition has revealed that many English teachers have shaky confidence when teaching pronunciation (Foote et al., 2016; Murphy, 2014); therefore, they limit pronunciation teaching to segmental features (Gilakjani, 2012) or simply disregard teaching it (Baker, 2011; MacDonald,2002). 


\section{Ml Macrothink}

Journal of Studies in Education

ISSN 2162-6952

2021, Vol. 11, No. 4

Due to insufficient training for pronunciation teaching (Baker, 2011), many teachers who still believe in native pronunciation are of the view that learning pronunciation is strenuous, so teaching it is futile (Gilakjani, 2012). Moreover, pronunciation is often bound to issues of identity and race in sophisticated sociocultural settings. Nonnative English-speaking teachers (NNESTs) may be challenged over their own perceived "flawed" pronunciation, feeling insecure when teaching it (Murphy, 2014). This lack of confidence can lead them to believe that teaching pronunciation is the responsibility of native English-speaking teachers (NESTs) (Levis, 2005), although NESTs' pronunciation teaching is often restricted to explicit error correction (Couper, 2017) and is rarely constructive (Foote et al., 2016).

\subsubsection{Pronunciation Teaching in Teacher Training Programs}

Like any other language skill, pronunciation instruction requires proficiency in teaching gained partially through academic study (Nunan \& Richards, 2009). Limited research on the impact of the role of training on pronunciation teaching (Wright, 2010) shows that, to a great extent, slim attention has been paid to this issue during the post-audiolingual era (Breitkreutz et al., 2002). As a result, many teachers have neither specific training for pronunciation teaching nor sufficient linguistic training in phonetics and phonology (Breitkreutz et al., 2002; Fraser, 2000), so they ignore or intuitively restrict teaching pronunciation to listening and repeating (Gilakjani, 2016).

Teacher training is so essential in pronunciation pedagogy that some teachers have reported it as a variable in choosing pedagogical approaches in the pronunciation classroom. Derwing (2010) highlights that if English teachers are armed with pronunciation teaching "tools," they can align it with other language skills in the classroom.

\subsubsection{Experience in Teaching}

Pronunciation is seldom aligned with other language skills (Gilakjani, 2016). This is because educational bodies have given the pronunciation pedagogy short shrift, as not many course designers have developed specific programs on pronunciation training (MacDonald, 2002). Alternatively, teachers may gradually adopt teaching methods and approaches through practice experience. Jones (1997) showed that novice NESTs used their intuition to select teaching approaches as an alternative for acquired training-based teaching knowledge. They predominantly employ explicit error correction (Couper, 2017) and listening and repetition (Foote et al., 2016). In contrast, experienced teachers often adapt and integrate pronunciation lessons into communicative activities, teaching them without students' knowledge (Baker, 2014).

It seems that the learning experience of NNESTs, who have learned English in a non-English environment, can assist them in shaping practical teaching knowledge. Prior learning experience significantly affects teachers' practical knowledge (Borg, 2003) because it shapes the basis of their L2 teaching by practicing the approaches that had worked for them when learning English (Meijer et al., 2001). 


\subsubsection{Students' Linguistic Profiles}

The linguistic differences between English and students' native languages, including phonological aspects, seem significant in language pedagogy. Adult language learners have already developed their L1 sound system and have tendencies to use the established sound patterns in the L2 (Leather \& James, 1991). Therefore, they tend to pick up and use the English sounds in their L1 inventory (Palmer et al., 2006), transferring L1 phonological features into the L2 (Nikbakht, 2010) to construct English oral skills. One way of avoiding using the L1 sound system in a manner that leads to misunderstanding may be using drills to teach sound discriminations based on the notion that perceiving a difference that does not occur in the L1 is a prerequisite for good pronunciation (Busa, 2008).

\section{Method}

This study investigates the approaches ESL and EFL teachers use in teaching pronunciation and the influencing factors on selecting those approaches. For this purpose, five teachers from around the world participated in this qualitative study.

\subsection{Research Design}

In investigating the approaches used by the participants and the variables affecting their pronunciation lesson delivery, which involves capturing in-depth data from a relatively small sample, a qualitative study seemed to be appropriate (Creswell \& Clark, 2004). Therefore, a qualitative study was used to collect, analyze, and discuss the data within an interpretivism paradigm.

\subsection{Sample}

Five English teachers participated in the study, which seems to be sufficient to compare teaching approaches. As long as the research questions are informed, the sample size of qualitative research is not an issue (Onwuegbuzie \& Leech, 2005). 
Table 1. Participants in the study.

\begin{tabular}{|c|c|c|c|c|c|c|c|}
\hline Participant* & Nationality & Degree & Training & $\begin{array}{c}\text { ESL } \\
\text { Experience }\end{array}$ & $\begin{array}{c}\text { EFL } \\
\text { Experience }\end{array}$ & NEST/NNEST & $\begin{array}{c}\text { Grade/ Level } \\
\text { Taught }\end{array}$ \\
\hline Rose & Australian & $\begin{array}{c}\text { BA in } \\
\text { Education }\end{array}$ & $\begin{array}{c}\text { Cert. IV } \\
\text { in } \\
\text { TESOL } \\
\text { (Note2) }\end{array}$ & Five years & Five years & NEST & $\begin{array}{c}\text { GE (Note } 3 \text { ) } \\
\text { Beginner-Advanced, } \\
\text { EAP (Note 4) }\end{array}$ \\
\hline Priscilla & Brazilian & BA & $\begin{array}{l}\text { CELTA } \\
\text { (Note 5) }\end{array}$ & Five years & - & NNEST & $\begin{array}{c}\text { GE } \\
\text { Beginner-Advanced }\end{array}$ \\
\hline Sakura & Japanese & $\begin{array}{c}\text { MA in } \\
\text { Education }\end{array}$ & $\begin{array}{l}\text { Graduate } \\
\text { Cert. in } \\
\text { TESOL }\end{array}$ & - & 26 years & NNEST & $\begin{array}{c}\text { GE Beginner- } \\
\text { Pre-intermediate }\end{array}$ \\
\hline Sarah & Iranian & $\begin{array}{l}\text { MA in } \\
\text { ELT }\end{array}$ & - & - & 19 years & NNEST & $\begin{array}{c}\text { GE } \\
\text { Beginner-Advanced }\end{array}$ \\
\hline Mike & British & $\begin{array}{l}\text { MA in } \\
\text { TESOL }\end{array}$ & $\begin{array}{l}\text { CELTA, } \\
\text { TESOL }\end{array}$ & Five years & Five years & NEST & $\begin{array}{l}\text { GE Beginner- } \\
\text { Advanced, EAP, } \\
\text { Cambridge tests }\end{array}$ \\
\hline
\end{tabular}

*Pseudonyms have been used throughout this study to maintain confidentiality.

The participants' ages ranged between 28 and 50, and their teaching experience varied between five and 26 years. Sakura's teaching experience had been limited to Japanese high schools, and the other participants had been teaching English in language schools.

\subsection{Procedure}

Questionnaires were forwarded to the participants via email. They completed the questionnaire in their own time and returned it electronically, one week later. Questionnaire responses were subsequently analyzed to design semistructured interviews.

\subsection{Ethical Considerations}

After verbal approval of participation, all participants were sent information and consent forms by email. The informants were reassured that the information gathered in the course of the study would not be disclosed, and pseudonyms would be used to preserve their anonymity.

\subsection{Data Collection Instruments}

In order to draw the most reliable conclusion from responses, a mixed data collection method was selected. A written questionnaire was first used to obtain initial data, including information about the respondents' personal status, education, and work experience. As the most frequently used tool for data collection (Adejimi et al., 2010), questionnaires enable researchers to capture data quickly and economically (Krathwohl, 1993). The questionnaire was created in a Word document specifically to explore participants' approaches as well as problems and challenges they might have encountered when teaching pronunciation. 
The study later proceeded with interviews, as the common device for a qualitative study (Hoyle et al., 2002). A semistructured interview (Kajornboon, 2005) was designed to elicit deep data (Mligo, 2016) by exploring the areas and ideas with regard to approaches to delivering pronunciation lessons. Moreover, the interviews captured missing data that the questionnaire had failed to collect (Roth, 1994). The interviews were approximately 30 minutes in length and contained open-ended questions for the participants to elaborate on their experiences and perceptions (Mligo, 2016).

Even though the interview questions were open-ended to solicit participants' perspectives with few or no imposed limitations (Chenail, 2011), discussions were not inappropriately diverted to nonrelated directions (Poggenpoel \& Myburgh, 2003), so that the captured data remained unbiased.

\subsection{Limitations of Study}

The present study explored approaches for pronunciation teaching by five participants, and therefore the results are not intended to be generalized or extrapolated.

\subsection{Data Analysis}

The questionnaires were carefully reviewed for missing data. A number of relevant questions were added to the interviews to bridge the data gap (Richards, 2003). Once the interviews were conducted, their transcriptions and the questionnaires were reviewed for content analysis. The content analysis identified patterns or themes from the data by organizing data into categories (Mayring, 2004).

In brief, for this study, a questionnaire and a semistructured interview were used to capture the data from five EFL and ESL teachers. The data were then initially coded for analysis and prepared for reporting. The following section will present the findings of the study.

\section{Findings}

Although CLT was the predominant teaching approach, the teachers occasionally used explicit pronunciation teaching (e.g., audiolingual techniques) to bridge the gap they assumed to be the CLT's pedagogical limitation. The study also showed that in delivering a pronunciation lesson, a number of variables influenced the choice of teaching approaches. These variables, directly or indirectly, affected these teachers as they tried to meet the lesson objectives. The influencing variables related to the teachers on choosing approaches to pronunciation pedagogy were teacher cognition, teacher training, and classroom experience.

The teachers also mentioned variables that directly affected their teaching approaches in a pronunciation classroom. These variables they reported as being student-related and include age, L1, and English competency level.

\subsection{Variables Related to Teachers}

As shown in Table 2, the participants reported three variables as applicable at the time of teaching pronunciation. Checkmarks in Table2 represent the reported variable by each participant. 
Table 1. Teacher-related variables for pronunciation pedagogy, as reported by participants.

\begin{tabular}{lccc}
\hline Participant & Cognition & Training & Experience \\
\hline Sarah & $\checkmark$ & $\checkmark$ & $\checkmark$ \\
Sakura & $\checkmark$ & $\checkmark$ & $\checkmark$ \\
Rose & $\checkmark$ & $\checkmark$ & $\checkmark$ \\
Priscilla & $\checkmark$ & $\checkmark$ & $\checkmark$ \\
Mike & $\checkmark$ & & $\checkmark$ \\
\hline
\end{tabular}

4.1.1. Teacher Cognition about Pronunciation

Teachers' cognition can be viewed and discussed as teachers' beliefs about their understanding of pronunciation and pronunciation pedagogy. The study showed that these factors directly influence the informants' choice of approach in a pronunciation classroom.

Table 2. Teacher cognition about pronunciation, as reported by participants.

\begin{tabular}{lccccc}
\hline Participant & Challenging & Segmentals & Suprasegmentals & Poor Training & $\begin{array}{l}\text { CLT } \\
\text { principles }\end{array}$ \\
\hline Sarah & $\checkmark$ & & $\checkmark$ & $\checkmark$ & $\checkmark$ \\
Sakura & $\checkmark$ & $\checkmark$ & $\checkmark$ & $\checkmark$ \\
Rose & $\checkmark$ & $\checkmark$ & $\checkmark$ & $\checkmark$ & $\checkmark$ \\
Priscilla & $\checkmark$ & & $\checkmark$ & & $\checkmark$ \\
Mike & $\checkmark$ & & $\checkmark$ & $\checkmark$ \\
\hline
\end{tabular}

As shown in Table 3, all participants believed that pronunciation is a challenging skill for L2 learners, so they reported having often skipped or ignored pronunciation modules in course books. Only one teacher believed that segmental features (i.e., vowells and consonants, minimal pairs, diphthongs) play a pivotal role in boosting learners' pronunciation skills. When asked about pronunciation pedagogy in teacher training programs, four participants reported a belief that teaching pronunciation had not been paid enough attention in their teacher training, causing a lack of confidence when delivering pronunciation lessons. All five teachers asserted their belief in CLT principles. They commented that CLT let them teach pronunciation without students' knowledge. However, alongside implicit teaching, all participants held the view that explicit pronunciation pedagogy is sometimes necessary.

\subsubsection{Pronunciation Teaching in Teacher Training Programs}

Language teacher training programs have been prevalent worldwide in recent years, and most English teachers have formal certification in ELT. 


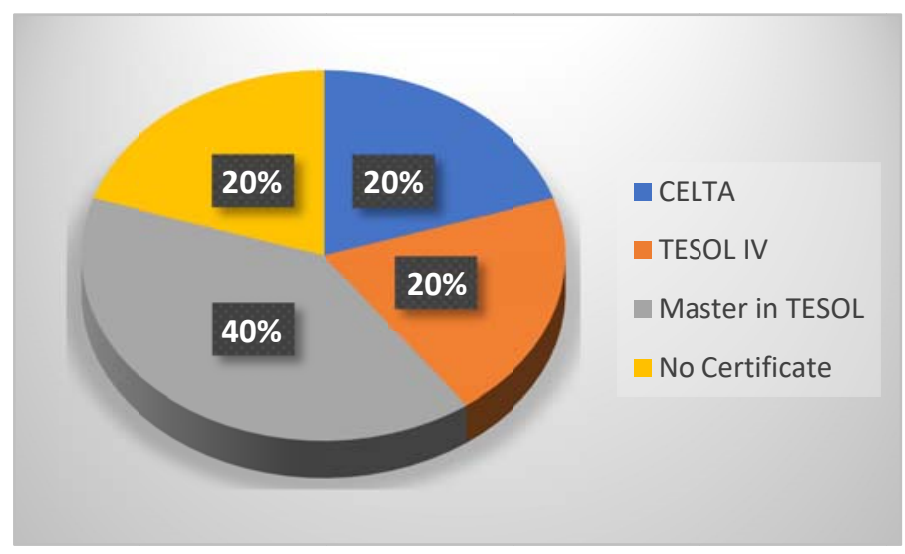

Figure 1. Teacher training programs, as reported by participants.

As shown in Figure 1, the questionnaire showed that four informants had completed an internationally recognized teacher training program (CELTA or TESOL). The fifth respondent had been awarded a master's degree in ELT in her native country, a program that had included a limited pronunciation training component. All five participants agreed that the teacher training programs positively affected their teaching experience; however, the training had contained a dearth of approaches, methods, and techniques for pronunciation instruction. Therefore, four teachers said they had developed pronunciation pedagogical skills by self-study and trial and error.

\subsubsection{Classroom Experience}

The classroom experience can be conceptualized as experience in teaching and experience in learning; both may influence language teaching outcomes. All five English teachers acknowledged teaching experience as the determining factor becausie there had been inadequate pre-service training on pronunciation pedagogy. In addition, the EFL teachers reported that their learning experience had cast a light on their students' pedagogical needs. English was not their native language, and they shared the L1 with learners, so they were aware of their language learners' phonological challenges.

\subsection{Variables Related to Students}

Further to the variables related to teachers, the informants reported a number of factors related to students that influenced their choice of approaches.

Table 3. Student-related influencing factors reported by participating teachers.

\begin{tabular}{lccc}
\hline Participant & Student Age & Student Linguistic Profile & Student L2 Proficiency \\
\hline Sarah & $\checkmark$ & $\checkmark$ & $\checkmark$ \\
Sakura & & $\checkmark$ & $\checkmark$ \\
Rose & $\checkmark$ & $\checkmark$ & $\checkmark$ \\
Priscilla & & & \\
Mike & $\checkmark$ & $\checkmark$ & \\
\hline
\end{tabular}

The variables related to students reported by the participants are shown in Table 4. 
Checkmarks display reported variables by each teacher.

\subsubsection{Student Age}

Three participating teachers considered age an influencing factor in pronunciation teaching. They argued that young learners require a different atmosphere and approach. They stated that young learners learn pronunciation quicker than older learners, so for younger learners, including teenagers, instruction might include the playing of appealing songs, and learners might be asked to repeat the song in peer groups. Both EFL teachers highlighted that they use drills in classes with adult learners to minimize fossilization (Note 6).

\subsubsection{Student Linguistic Profile}

The teachers reported that students' L1 was a significant reason for explicit pronunciation teaching. Although all participating teachers unanimously stressed their use of CLT in teaching pronunciation, they acknowledged that explicit pronunciation teaching was sometimes inevitable. Both EFL teachers, who shared the L1 with their students, were aware of phonological similarities and differences between their native languages and English. They knew how linguistic rules of the learners' L1 are transferred to English. Therefore, they considered students' L1 an influential variable for teaching explicit pronunciation, that is, listening and repetition.

Two ESL teachers addressed students' linguistic and cultural profiles as a direct factor that affected pronunciation teaching. They highlighted the existence of a mixture of various language backgrounds in most ESL contexts, so it is impossible to compare English sounds with the L1 because there are multiple first languages in a single classroom. The respondents added that students from specific cultural backgrounds are sometimes diffident, so these teachers often use listen-and-repeat techniques to engage them in pronunciation lessons.

\subsubsection{Learner's Level of Proficiency}

Three teachers pointed out that pronunciation teaching in a CLT classroom with relatively low-level learner capacities is quite unfeasible because learners' English phonological inventory has not been shaped completely. The teachers indicated that they use a mechanical approach such as the audiolingual approach (e.g., drills, repetition, and call and response) in teaching pronunciation to lower-level learners. In comparison, high-level students are proficient enough to participate in communicative activities with the teacher's minimal intervention.

\section{Discussion}

This section aims to answer the research questions based on the findings. The research questions of the study were these:

1) What variables influence English language teachers' approaches to teaching pronunciation lessons in EFL and ESL classrooms?

2) What approaches do English language teachers use in EFL/ESL contexts?

3) How are these approaches different?

Although the discussion of each of these questions provides valuable insight into pedagogical approaches and the influencing variables, the findings of the present study are not intended to 


\section{Macrothink}

be generalized. However, it is reasonable to argue that EFL and ESL teachers may encounter similar variables during pronunciation instruction.

\subsection{Variables Influencing Pedagogical Approach}

The study's findings showed two main variables influencing teaching approaches in a pronunciation classroom: variables related to the teachers and variables related to students. Variables related to the teachers encompassed teacher cognition, teacher training, teaching and learning experience, and the use of other language skills.

\subsubsection{Teacher Cognition}

All participants concurred that teacher cognition could significantly affect pronunciation instruction causing pronunciation to be regarded as an inseparable element of the spoken constituent or being given short shrift. Figure 2 categorizes the participating teachers' cognition on pronunciation teaching.

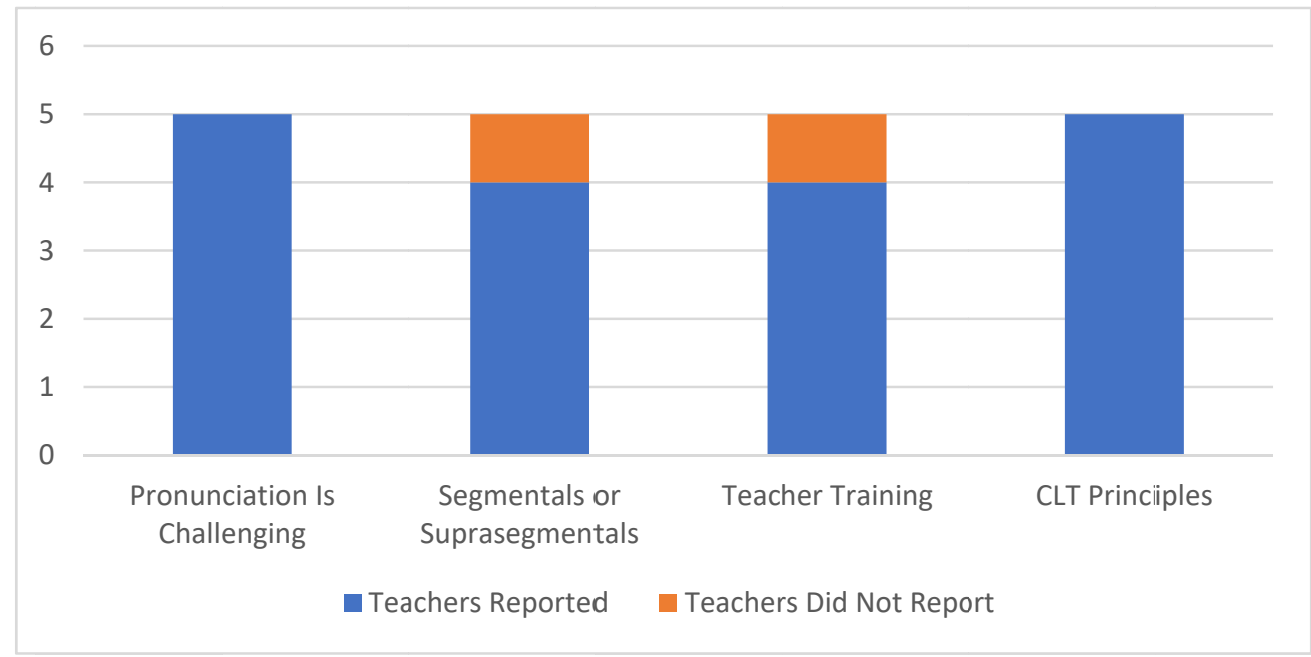

Figure 2. Teacher cognition influence in choosing a pedagogical approach

It is generally believed that L2 pronunciation is a challenging language skill to acquire. All five respondents concurred that the challenges in acquiring adequate pronunciation are a severe setback for student learning pronunciation, and therefore, teachers sometimes ignore this aspect of L2 instruction. Previous studies have also shown similar findings: pronunciation is a strenuous skill to acquire, and students often spend time with it only grudgingly (Aliaga García, 2007; Gilakjani, 2016; Sadeghi \& Mashhadi, 2016). A second challenge in regard to pronunciation reported by the informants is learners' perception of pronunciation learning- that is, their desire to acquire native or native-like pronunciation. This finding contradicts the fundamentals of CLT, in which function rather than form is the focus (Desai, 2015). In other words, intelligible pronunciation should be the goal in a CLT classroom (Gilakjani, 2012).

Segmental and suprasegmental features are speech attributes that provide useful information in the recognition of spoken language. Four participants indicated that they emphasized suprasegmentals over segmentals in their CLT classrooms because they believed that mispronunciation of suprasegmental features might lead to misunderstanding the spoken 
language. These teachers highlighted that students with various L1s might have different phonological rules than English, so the teachers prioritized teaching suprasegmentals. Previous studies by Celce-Murcia et al. (1996), Fraser (2002), and Levis and Grant (2003) have indicated that CLT is a function-based approach that stresses overall pronunciation through achieving communicative competence. A crucial aspect of communicative competence is achieving intelligible pronunciation by learning and improving suprasegmental features, as they make meanings in spoken language (Celce-Murcia et al., 1996, Fraser, 2000; Zarifi \& Sayyadi, 2015). In contrast, one ESL teacher prioritized segmental features because she believed segmentals were the fundamentals of pronunciation and most English learners could not distinguish similar sounds or produce them correctly to avoid errors in verbal interactions. The latter finding contradicts the fact that suprasegmentals have been shown to weigh more heavily in conveying speech understandability (Celce-Murcia et al., 1996).

Most participants indicated that inadequate training had been the chief reason for their lack of confidence in delivering pronunciation lessons. Four participating teachers confirmed their belief in the role of training as a confidence booster, and that being armed with it could have dramatically increased their confidence. This statement is consistent with the findings of Breitkreutz et al.(2002), Derwing \& Munro (2005), and Foote et al. (2016), in which limited teacher training has been shown to be a constraint on effective pronunciation teaching. These teachers added that a seminar or self-study on pronunciation pedagogy could increase their confidence remarkably.

All five teachers confirmed their belief in CLT principles. CLT is founded upon principles that suggest teaching language skills should be incorporated into various classroom activities (Desai, 2015). Similarly, the principles of CLT propose integrating pronunciation into classroom activities such as speaking and listening activities so that students can learn pronunciation even without their knowledge. Such integration enhances the chances of developing two or more language skills, including pronunciation, simultaneously (Baker, 2014; Foote et al., 2016). Likewise, the participant teachers were convinced that CLT is the only approach that allows them to teach implicit pronunciation in routine speaking activities. Because CLT is function focused, it lets learners take active parts in classroom tasks without teacher intervention, and the teachers, in lieu of having students repeat words or phrases, provide monitoring only. However, the participant teachers doubted the feasibility of applying implicit pronunciation pedagogy at all times because they believed that all the phonological needs of learners could not be addressed solely by implicit teaching. This is consistent with previous studies such as that of Murphy (2011), who found that most ESL participants in his study successfully applied audiolingual techniques (i.e., listen and repeat) or provided corrective feedback while learners read aloud in a CLT classroom.

\subsubsection{Teacher Training}

Teacher training relates to fundamental requirements for language teaching, which prepares teachers to undertake their pedagogical role in the classroom. Four teachers expressed the belief that teacher training could pave the path for successful language pedagogy, including pronunciation. They complained about the absence or minimal attention to pronunciation in teacher training programs. Scholars have concluded that teachers with limited training might 
be unable to choose a pedagogical approach suitable for diverse classes (Breitkreutz et al., 2002; Derwing \& Munro, 2005; Foote et al., 2016). Thus, teachers with any type of training for pronunciation teaching (i.e., formal, informal, and self-study) can be effective facilitators for their students; in contrast, a lack of thorough training in pronunciation teaching is a constraint hindering successful pronunciation instruction.

\subsubsection{Teaching and Learning Experience}

Teaching experience has been defined as meeting learners regularly, develloping instructional materials, planning and delivering language lessons, and assessing student performance (Derwing, 2008). Teachers with years of experience can often use their skills to exploit almost all classroom activities for pronunciation teaching (Baker, 2014), and novice teachers use their intuition and trial and error to find teaching approaches (Foote et al., 2016; Jones, 1997). All five teachers deemed teaching experience a variable to affect the selection of their language teaching approach. They confirmed that teaching experience is a crucial element, especially given the dearth of training in pronunciation instruction; thus, teaching experience can act as a training alternative in such situations.

The participants' prior language learning experiences were also effective in delivering pronunciation lessons. The EFL teachers acknowledged their learning experience as the basis of L2 language teaching (Borg, 2003), including pronunciation instruction. The NNESTs who shared the L1 with their students in EFL contexts were aware of the students' linguistic similarities and differences with those of English. Therefore, they could address the students' phonological requirements by utilizing their own learning experience and the teaching approaches that had helped them learn English.

\subsubsection{Variables Related to Students}

Student age, linguistic profile, and L2 proficiency levels were reported to play roles in offering teaching approaches by the teachers.

In delivering pronunciation lessons, teachers should keep young language learners amused and motivated, and therefore, boring techniques such as listen and repeat should be avoided (Huyen \& Nga, 2003). One EFL and two ESL participant teachers acknowledged using CLT with engaging teaching activities for younger students, such as listening to songs, playing games, and imitating pop and cinema celebrities. All teachers reported using the audiolingual approach in situations where they believed CLT was not helping with adult learners. This finding, however, contradicts the view of Richards and Rodgers (2014) that discrete pronunciation instruction should be avoided in a CLT classroom.

Four participants (i.e., two EFL and two ESL teachers) recognized L1 influence on the teaching approach in the classroom. Students often use their existing linguistic profile to construct English language skills. Thus, most learners transfer linguistic rules, including phonological rules, from their L1 to the target language (Palmer et al., 2006). The EFL teachers were well aware of the phonological differences and similarities of their students' L1 and English because they shared the native language with the students, so they were convinced that students' mispronunciation could be fixed by explicit pronunciation teaching. The ESL teachers also used explicit techniques to offer students insight into the sound 
variations of their language and English. All four teachers used the listen-and-repeat technique to target the mispronounced sounds. These teaching techniques are commonly practiced within the Audiolingual approach and contradict CLT fundamentals (Burns \& Seidlhofer, 2010).

The teachers considered students' L2 proficiency levels a factor in selecting the teaching approach. Principles of CLT assert that CLT is a pedagogical approach that can be used at all levels and in all contexts (Desai, 2015; Richards, 2005; Richards \& Rodgers, 2014); thus, the study results contradicted the literature. The EFL teachers and an ESL teacher concurred that students at elementary levels could not honor CLT because of their limited linguistic knowledge. The teachers believed that these students required mechanical exercises and that an audiolingual pedagogy seemed the most appropriate approach. Therefore, these teachers taught explicit pronunciation by explaining phonological lessons verbally and then getting the learners to repeat what they had learned.

\subsection{ELT Approaches in EFL and ESL Contexts}

The study revealed that even though the EFL and ESL teachers, by and large, had a positive attitude toward CLT, a combination of explicit and implicit pronunciation instruction was used by the participants. The teachers practiced CLT predominantly, and the audiolingual approach was the alternative when CLT was perceived to be impractical.

Although all teachers practiced CLT in their classrooms, they sometimes used other approaches, chiefly listening and repetition, to complement CLT's inability in pronunciation instruction. This finding is inconsistent with the conclusion of Richards and Rodgers (2014), who insisted on teaching implicit pronunciation in a CLT classroom. In other words, CLT emphasizes function (Desai, 2015), and functional pronunciation is grasped through integrated communicative activities (e.g., role play) even without learners" knowledge (Baker, 2014).

Although CLT recommends implicit pronunciation teaching, experts such as Busa (2008) have recommended using drills when learners cannot distinguish English sounds from those of their L1, causing misunderstanding. So the listen-and-repeat approach can be justified in EFL contexts where learners are exposed to the English sound system in their classrooms only.

\subsection{Differences between ELT Approaches in EFL and ESL}

The EFL teachers knew similarities and differences between learners' L1 and the English sound system. Moreover, they were aware that these differences might cause mispronunciation leading to misunderstanding. Therefore, audiolingual techniques were used in their classrooms, although they believed in and practiced CLT. However, CLT principles focus on reaching intelligible pronunciation (Gilakjani, 2011) through gaining communicative competence (Richards \& Rodgers, 2014). Communicative competence is the ultimate outcome of CLT in every language classroom (Richards, 2005). Because the EFL teachers came from the same L1 background, they used the approach that had worked well for them while learning English. Similarly, Borg (2003) considered teaching and learning experience as influential in selecting a teaching approach. 


\section{NI Macrothink}

ESL students are exposed to native pronunciation, so it is assumed that they can learn intelligible pronunciation faster, and ESL teachers can adhere to CLT principles and employ CLT in their English classrooms more easily than in EFL settings. However, the participants used explicit pronunciation teaching when there was a need for further explanations or some phonological errors persisted. This finding shows misalignment with earlier studies that have encouraged teachers to integrate pronunciation instruction into other language skills (Desai, 2015; Richards, 2005), prioritizing implicit teaching in their classrooms (Gilakjani, 2011).

\section{Conclusion}

This study aimed to illuminate ELT approaches in EFL and ESL classrooms for pronunciation instruction and the variables affecting the choice of approaches. The results indicate that among the participants in this study, CLT is practiced in almost all English classrooms and where teachers believe that CLT is nonfunctional, they employ the audiolingual approach, mainly the listen-and-repeat technique. Further findings show that two types of variables influence teachers' selection of the approaches: variables related to teachers and variables related to students. Teacher-related variables encompass cognition, training, and experience, and student-related variables include age, L1, and L2 proficiency levels.

The findings will provide English language teachers with insights into the approaches used in CLT classrooms in EFL and ESL settings and how the variables influence the selection of these approaches. Therefore, this awareness can encourage English teachers to deploy approaches suitable for their students considering the influencing factors. This study examined the approaches used in CLT classrooms, and the results, to a great extent, confirm the current theories of teaching pronunciation in the context of CLT, that is, integrating pronunciation instruction into the other speaking activities through classroom communicative activities.

Only five participants took part in this qualitative study. Therefore, this study cannot be generalized due to the small sample. It would be worthwhile to conduct similar research with a larger sample that varies in age range and teaching experience, and representing various EFL and ESL classrooms worldwide. A larger sample would better indicate the pedagogical approaches English teachers use in their classrooms. In addition, a mixed method of qualitative and quantitative analysis would more greatly support or challenge the current theories about methods and approaches of pronunciation instruction.

\section{Notes}

Note 1. Inner circle refers to English variations that are primarily used by most of the population of countries such as the United States, the United Kingdom, Australia, and New Zealand. (Kachru, 1992).

Note 2. Teaching English to Speakers of Other Languages. A certificate for teachers in the EFL/ESL industry.

Note 3. General English.

Note 4. English for Academic Purposes.

Note 5. Cambridge Certificate in English Language Teaching to Adults. 
Note 6. Fossilization describes the process in which erroneous language patterns becomes a habit in the L2 acquisition and cannot be easily corrected.

\section{References}

Adejimi, A., Oyediran, O., \& Ogunsanmi, E. (2010). Employing qualitatively enriched semi structured questionnaire in evaluating ICT impact on Nigerian 'construction chain integration'. The Built \& Human Environment Review, 3(1), 49-62.

Aliaga García, C. (2007). The role of phonetic training in L2 speech learning. Paper presented at the Proceedings of the Phonetics Teaching and Learning Conference. https://www.phon.ucl.ac.uk/ptlc/proceedings/ptlcpaper_32e.pdf

Baker, A. (2011). ESL teachers and pronunciation pedagogy: Exploring the development of teachers' cognitions and classroom practices. The University of Wollongong. https://ro.uow.edu.au/edupapers/368

Baker, A. (2014). Exploring teachers' knowledge of second language pronunciation techniques: Teacher cognition

ns, observed classroom practices, and student perceptions. TESOL Quarterly, 48(1), 136-163. https://doi.org/10.1002/tesq.99

Binte Habib, R. (2013). Intelligibility in EIL Pronunciation: An Analysis. IOSR Journal of Humanities and Social Science (IOSR-JHSS), 14, 21-26. https://doi.org/10.9790/1959-1442126

Borg, S. (2003). Teacher cognition in language teaching: A review of research on what language teachers think, know, believe, and do.Language teaching, 36(2), 81-109. https://doi.org/10.1017/S0261444803001903

Borg, S. (2015). Teacher cognition and language education: Research and practice. Bloomsbury Publishing.

Breen, M. P., \& Candlin, C. N. (1980). The essentials of a communicative curriculum in language teaching. Applied Linguistics, 1(2), 89-112. https://doi.org/10.1093/applin/I.2.89

Breitkreutz, J., Derwing, T. M., \& Rossiter, M. J. (2002). Pronunciation teaching practices in Canada. TESL Canada Journal, 51-61. http://doi.org/10.18806/tesl.v19i1.919

Brown, H. D. (2016). Teaching by principles. Pearson Education.

Burns, A., \& Claire, S. (2003). Clearly speaking: Pronunciation in action for teachers. AMEP Research Centre Macquarie University.

Burns, A., \& Seidlhofer, B. (2010). Speaking and pronunciation. In An introduction to applied Linguistics, pp.197-214. Routledge.

Busa, M. G. (2008). New perspectives in teaching pronunciation. In From Didactas to Ecolingua: an ongoing research project on translation and corpus linguistics. pp.165-182. 
di

Trieste.

https://www.openstarts.units.it/bitstream/10077/2850/1/bus\%C3\%A0.pdf

Celce-Murcia, M., Brinton, D. M., \& Goodwin, J. M. (1996). Teaching pronunciation: A reference for teachers of English to speakers of other languages. Cambridge University Press.

Chenail, R. J. (2011). Interviewing the investigator: Strategies for addressing instrumentation and researcher bias concerns in qualitative research. Qualitative Report, 16(1), 255-262.

Chiu, H. (2008). Practical understandings: Teachers' beliefs and practices in pronunciation teaching (Master's thesis). Retrieved from ProQuest Dissertations and Theses database.(1460681).

https://www.proquest.com/dissertations-theses/practical-understandings-teachers-beliefs/docv iew/304842421/se-2?accountid=12763

Chomsky, N. (1957). Syntactic Structures (The Hague: Mouton, 1957). Review of Verbal Behavior by BF Skinner, Language, 35, 26-58. https://doi.org/10.2307/411334

Couper, G. (2017). Teacher cognition of pronunciation teaching: Teachers' concerns and issues. TESOL Quarterly, 51(4), 820-843. https://doi.org/10.1002/tesq.354

Creswell, J. W., \& Clark, V. L. P. (2004). Principles of qualitative research: Designing a qualitative study. Office of Qualitative \& Mixed Methods Research, University of Nebraska, Lincoln.

Dalton, C., \& Seidlhofer, B. (1994). Pronunciation. Oxford University Press.

Derwing, T. M. (2003). What do ESL students say about their accents? Canadian Modern Language Review, 59(4), 547-567. https://doi.org/10.3138/cmlr.59.4.547

Derwing, T. M. (2008). Curriculum issues in teaching pronunciation to second language learners. Phonology and Second Language Acquisition, 36, 347-369. https://doi.org/10.1075/sibil.36.17der

Derwing, T. M., \& Munro, M. J. (2005). Second language accent and pronunciation teaching: A research-based approach. TESOL Quarterly, 39(3), 379-397. https://doi.org/10.2307/3588486

Desai, A. A. (2015). Characteristics and principles of communicative language teaching. International Journal of Research in Humanities \& Social Sciences, 3(7), 48-50.

Field, J. (2005). Intelligibility and the listener: The role of lexical stress. TESOL Quarterly, 39(3), 399-423. https://doi.org/10.2307/3588487

Florez, M. C. (1998). Improving adult ESL learners' pronunciation skills: ERIC, National Clearinghouse for ESL Literacy Education.

Foote, J. A., Holtby, A. K., \& Derwing, T. M. (2011). Survey of the teaching of pronunciation in adult ESL programs in Canada, 2010. TESL Canada Journal, 29 (1), 1-22. https://doi.org/10.18806/tesl.v29i1.1086 
Foote, J. A., Trofimovich, P., Collins, L., \& Urzúa, F. S. (2016). Pronunciation teaching practices in communicative second language classes. The Language Learning Journal, 44(2), 181-196. https://doi.org/10.1080/09571736.2013.784345

Fraser, H. (2000). Coordinating improvements in pronunciation teaching for adult learners of English as a second language. DETYA (ANTA Innovative project).

Fraser, H. (2002). Change, challenge, and opportunity in pronunciation and oral communication. Paper presented at the Plenary Address at English Australia Conference, Canberra.

Gilakjani, A. P. (2011). A study on the situation of pronunciation instruction in ESL/EFL classrooms. Journal of studies in education, 1(1), 1-15. http://dx.doi.org/10.5296/jse.v1i1.924

Gilakjani, A. P. (2012). A study of factors affecting EFL learners' English pronunciation learning and the strategies for instruction. International Journal of Humanities and Social Science, 2(3), 119-128.

Gilakjani, A. P. (2016). What Factors Influence the English Pronunciation of EFL Learners? Modern Journal of Language Teaching Methods (MJLTM), 6(2), 314-326.

Harmer, J. (2007). The practice of English language teaching. Pearson Longman.

Hayati, A. M. (2010). Notes on Teaching English Pronunciation to EFL Learners: A Case of Iranian High School Students. English Language Teaching, 3(4), 121-126. https://doi.org/10.5539/elt.v3n4p121

Hosen, M. D. A. (2015). A Historical Overview of Communicative Language Teaching in Bangladesh: Problems, Prejudices and Resolutions. International Journal of English and Literature (IJEL), 5(2).

Hoyle, R., Harris, M., \& Judd, C. (2002). Research Methods in Social Relations. Thomson Learning.

Huyen, N. T. T., \& Nga, K. T. T. (2003). Learning vocabulary through games. Asian EFL Journal, 5(4), 90-105.

James, R. (2010). Teaching pronunciation gets a bad RAP: A framework for teaching pronunciation. Hankuk: University of Foreign Studies.

Jenkins, J. (2004). Research in teaching pronunciation and intonation. Annual Review of Applied Linguistics, 24, 109-125. https://doi.org/10.1017/S0267190504000054

Jones, R. H. (1997). Beyond "listen and repeat": Pronunciation teaching materials and theories of second language acquisition. System, 25(1), 103-112. https://doi.org/10.1016/S0346-251X(96)00064-4

Kachru, B. B. (1992). World Englishes: Approaches, issues and resources. Language Teaching, 25(1), 1-14. https://doi.org/10.1017/S0261444800006583 
Kajornboon, A. B. (2005). Using interviews as research instruments. E-journal for Research Teachers, 2(1), 1-9.

Kang, O., Rubin, D., \& Pickering, L. (2010). Suprasegmental measures of accentedness and judgments of language learner proficiency in oral English. The Modern Language Journal, 94(4), 554-566. https://doi.org/10.1111/j.1540-4781.2010.01091.x

Keshmirshekan, M. H. (2019). Improving Upper-intermediate EFL Learners' Communicative Competence through Authentic Materials. Theory and Practice in Language Studies, 9(8), 956-964. http://dx.doi.org/10.17507/tpls.0908.10

Koosha, M., \& Yakhabi, M. (2013). Problems associated with the use of communicative language teaching in EFL contexts and possible solutions. International Journal of Foreign Language Teaching and Research, 1(2), 77-90.

Krathwohl, D. R. (1993). Methods of educational and social science research: An integrated approach: Longman/Addison Wesley Longman.

Leather, J., \& James, A. (1991). The acquisition of second language speech. Studies in Second Language Acquisition, 13(3), 305-341. https://doi.org/10.1017/S0272263100010019

Levis, J. M. (2005). Changing contexts and shifting paradigms in pronunciation teaching. TESOL Quarterly, 39(3), 369-377. https://doi.org/10.2307/3588485

Levis, J. M., \& Grant, L. (2003). Integrating pronunciation into ESL/EFL classrooms. Tesol Journal, 12(2), 13-19. https://doi.org/10.1002/j.1949-3533.2003.tb00125.X

Macdonald, S. (2002). Pronunciation-views and practices of reluctant teachers. Prospect, 17(3), 3-18.

Marks, J. (2006). Pronunciation in coursebooks again. Speak Out, 36, 33-35.

Mayring, P. (2004). Qualitative content analysis. In A companion to qualitative research, 1(2004), 159-176.

McDonough, J. (1999). Pronunciation teaching. In Encyclopedic Dictionary of Applied Linguistics (pp. 265-267). Blackwell.

Meijer, P. C., Verloop, N., \& Beijaard, D. (2001). Similarities and differences in teachers' practical knowledge about teaching reading comprehension. The Journal of Educational Research, 94(3), 171-184. https://doi.org/10.1080/00220670109599914

Mligo, E. S. (2016). Introduction to research methods and report writing: A practical guide for students and researchers in social sciences and the humanities. Wipf and Stock Publishers.

Murphy, J. M. (2014). Teacher training programs provide adequate preparation in how to teach pronunciation. In Pronunciation myths: Applying second language research to classroom teaching, 188-224.

Nikbakht, H. (2010). EFL pronunciation teaching: A theoretical review. Journal of English Language Pedagogy and Practice, 4(8), 146-174. 
Nunan, D., \& Richards, J. C. (2009). Second language teacher education. Cambridge University Press Cambridge.

Onwuegbuzie, A. J., \& Leech, N. L. (2005). The role of sampling in qualitative research. Academic Exchange Quarterly, 9(3), 280-285.

Palmer, B. C., Chen, C. I., Chang, S., \& Leclere, J. T. (2006). The impact of biculturalism on language and literacy development: Teaching Chinese English language learners. Reading Horizons: A Journal of Literacy and Language Arts, 46(4), 2. https://scholarworks.wmich.edu/reading_horizons/ vol46/iss $4 / 2$

Poggenpoel, M., \& Myburgh, C. (2003). The researcher as research instrument in educational research: A possible threat to trustworthiness? Education (Chula Vista), 124(2), 418.

Richards, J. C. (2005). Communicative language teaching today. SEAMEO Regional Language Centre Singapore.

Richards, J. C., \& Rodgers, T. S. (2014). Approaches and methods in language teaching. Cambridge University Press.

Richards, K. (2003). Qualitative inquiry in TESOL. Springer. https://doi.org/10.1057/9780230505056

Roth, P. L. (1994). Missing data: A conceptual review for applied psychologists. Personnel psychology, 47(3), 537-560. https://doi.org/10.1111/j.1744-6570.1994.tb01736.x

Sadeghi, M., \& Mashhadi, H. D. (2016). The effect of using phonetic websites on Iranian EFL learners'word level pronunciation. International Journal of Research in Education

Saito, K. (2013). Reexamining effects of form-focused instruction on L2 pronunciation development: The role of explicit phonetic information. Studies in Second Language Acquisition, 35(1), 1-29. https://doi.org/10.1017/S0272263112000666

Savignon, S. J. (2008). Interpreting communicative language teaching: Contexts and concerns in teacher education. Yale University Press.

Sifakis, N. C., \& Sougari, A. M. (2005). Pronunciation issues and EIL pedagogy in the periphery: A survey of Greek state school teachers' beliefs. TESOL Quarterly, 39(3), 467-488. https://doi.org/10.2307/3588490

Sung, C. (2005). An action research for communicative English teaching implemented in an elementary school: An example of fourth graders. Journal of National Taipei University of Education, 18(2), 267-296.

Waniek-Klimczak, E. (2011). "I Am Good at Speaking, But I Failed My Phonetics Class”'Á Pronunciation and Speaking in Advanced Learners of English. Speaking and Instructed Foreign Language Acquisition, 57, 117. Multilingual Matters. https://doi.org/10.21832/9781847694126-010 
Wright, T. (2010). Second language teacher education: Review of recent research on practice. Language Teaching, 43(3), 259-296. https://doi.org/10.1017/S0261444810000030

Zarifi, A., \& Sayyadi, A. (2015). How English suprasegmental features of pronunciation are viewed and treated by instructors in Iranian private language centers. Theory and Practice in Language Studies, 5(6), 1166-1172. https://doi.org/10.17507/tpls.0506.06 